\title{
Coastal Community Health Behavior: Implementation of the 7 Pillars of the Healthy Living Community Movement (Germas)
}

\author{
Muria Herlina \\ Universitas Bengkulu, Indonesia \\ Email:mherlina@unib.ac.id
}

\begin{abstract}
The purpose of this study was to determine the implementation of the 7 pillars of the healthy living community movement (Germas) in-depth and comprehensively. The research location was in Kampung Melayu Sub-District, a coastal area of Bengkulu City. This research method uses qualitative and quantitative approaches or joint research and uses techniques in one phase/research period. Data collection was carried out by using questionnaires to 125 respondents. Qualitatively obtained 17 informants through the sample aims, data collection through in-depth interviews, observation, and FGD, using matrix table analysis. The results of the study based on statistical tests found that 6 variables with $p$-values $>0.05$, namely father's education, mother's education, highest education in the family, ethnicity, rheumatism / joint pain, and vision. The results of in-depth interviews show that the most difficult behavior to change is the behavior to stop smoking because it has become a habit, it is not usual to regularly check the health and eating fruit has not been a priority, and daily work is assumed to be doing physical activity.
\end{abstract}

Keywords: Implementation, Germas, community, coastal.

\section{A. INTRODUCTION}

Coastal communities are people who live or live in coastal areas and in general, their sources of economic life depend directly on the use of marine and coastal resources. Coastal management has not been implemented in an integrated manner but is still sectoral (Pramudyanto, 2014). Coastal areas which are administratively far from the city center, allow for health problems caused by inadequate access and infrastructure due to geographical conditions (Lasabuda, 2013; Anwar, et.al, 2016) Coastal areas according to Law Number 27 of 2007, is a transitional area between land and sea ecosystems determined by 12 miles of territorial boundaries towards waters and regency/city boundaries inland.

According to Mboi (2015), coastal communities, including fishermen, have high health risks, so special attention needs to be paid to health development efforts. The Central Statistics Agency (2011) reports that there are around 8,090 coastal villages in Indonesia, spread in 300 coastal districts/cities. He explained that out of 234.2 million inhabitants of Indonesia, there were 67.87 million people working in the informal sector, and around $30 \%$ or 20.36 million of them were fishermen, most of whom lived in coastal areas. 
Indonesia is facing a triple burden health problem, making it one of the fundamental issues. Infectious diseases, increased non-communicable diseases (PTM) and diseases that should have been resolved reappeared, such as acute respiratory infections, tuberculosis, and diarrhea are the most diseases in health services. PTM such as Stroke, Coronary Heart Disease (CHD), Cancer and Diabetes actually occupy the highest rank, generally, the cause of the disease is a human lifestyle. One of the programs to mitigate health problems, the government made a program called the Healthy Living Community Movement (GERMAS), which was initiated by the Ministry of Health, starting on 15 November 2016, the activity was listed in Presidential Instruction Number 1 of 2017, consisting of seven pillars namely (1) Conducting Physical Activity, (2) Consuming Vegetables and Fruits, (3) Not smoking (4) Not Consuming Alcohol, (5) Routinely Checking Health, (6) Cleaning the Environment, and (7) Using Latrines. Aiming that the community behaves in a healthy manner, the creation of a clean environment so that it is expected to have an impact on health that is maintained, community productivity increases and costs incurred for treatment will decrease (Ministry of Health Republic of Indonesia, 2017).

Bengkulu Province has a coastal area of approximately $500 \mathrm{Km}$ Yuliesti (2017) Regional Action Plan Activities (RAD) namely maritime economic development in Bengkulu Province in 2017-2020, conducted in 7 (seven) locations, namely 6 (six) districts and one Bengkulu City which has a coastal area. (BP3D Bengkulu, 2017). In addition to providing economic benefits, the natural wealth of coastal areas also enables the preservation of other social life such as education and health of the region. But still must pay attention to environmental principles that also require the role of universities (Mersyah, 2018), as in the vision and mission of the University of Bengkulu, contained in the Development Master Plan (RIP), including the target of research studies in coastal communities.

In a study in the coastal area of Indramayu, fishing families' environmental conditions, namely smoking in the house, were found as many as 49.2 and allowed to defecate (BAB) infants in any place reaching 93.35 and $65.9 \%$, disposing of waste and disposing of trash in the open (Latif Idham, 2016). In addition, based on the findings (Herlina \& Permata, 2019; Hidana, et al. 2018), it was found that the health of coastal communities needs to get special attention from the government because posyandu activities or other health services have not been running optimally. This means that most coastal communities pay little attention to family health. The results of the Nadya et. al (2017) of junior high school students in Denpasar Bali who are related to GERMAS, it was found that the majority of female respondents had a good attitude towards fruit and vegetable consumption that was equal to $86.2 \%$, compared to male respondents only $13.8 \%$ consumed fruit and vegetables.

Another study conducted on the coast of Kenya by (Abubakar, at. Al, 2016; Muraya, at. Al 2017) found that HIV infection in Kenya due to poverty, poor mental health, 
lack of health access, and poor physical environment, affected treatment. HIV patients in the coastal region of Kenya, even mothers tend to be blamed for their children's poor health. Also in India precisely in Rural Coastal Odisha is a coastal area found that health problems are worrying and require remedial action, because of the hierarchy of power and dynamics in the household, namely limiting women's participation in hygiene decision-making processes, such as overcoming the problem of lack of proper latrines, husband's family participation is needed, male or female, to realize the importance of building latrines in building houses (Routray, et. al, 2017).

In Indonesia the GERMAS program has been running for more than 3 years, ironically there are still many health behavior problems, especially in coastal communities, one example of the results of research conducted in Poso District, regarding routine health checks, one of Germas activities, shows only 19,5\% of respondents use health services with good perception, meaning $80.5 \%$ perceived barrier (perceived barrier). The community has not yet visited Puskesmas in the context of obtaining health services. Some individuals prefer to do self-medication or seek treatment that is considered better than having to visit the Puskesmas (Napirah, 2016).

Referring to the above phenomenon, fishermen are said to be contributors to a fairly high poverty rate, impacting on health. Much research has been done in coastal areas, but specifically studying GERMAS in coastal areas is still a step. There are at least 4 (four) priorities of this research, namely (1) Supporting the Sustainable Development Goals (SDGs) program in 2030, including the community must be guaranteed to be able to buy safe, affordable and nutritious needs and get access to clean water and sanitation, besides the beach/coastal and ocean is a very valuable asset, influencing community survival, (2) Nationally supporting the Ministry of Health, including the Healthy Living Community Movement (GERMAS) program, (3) Supporting Bengkulu City's vision and mission including 'Bengkulu Kota Sehat' and (4) Finding correlations and identifying GERMAS implementation and finding solutions as a model for improving people's healthy behavior, especially in coastal areas.

\section{B. METHODS}

The location of the research in Bengkulu City in Kampung Melayu Sub-district was the reason that the location was determined because it is one of the largest coastal areas in the city of Bengkulu (Suyanto, 2016) and is a Prosperous Fishermen Village Area. This research uses qualitative and quantitative approaches or joint research. using techniques in one phase that is using qualitative and quantitative approaches simultaneously in one phase/research period. Aims to obtain comprehensive and in-depth data about the seven pillars of the implementation of the meaning and correlation of GERMAS. Qualitatively to understand social phenomena or phenomena, it is more focused on a complete picture of the phenomena studied in a particular socio-cultural order (Neuman, 2016; Martha \& Kresno, 2016). Quantitatively to determine the socio- 
demographic correlation with the implementation of GERMAS which includes 7 (seven) pillars using statistical analysis quantitative analysis techniques, using SPSS 23 program.

Data collection techniques using questionnaires to 125 respondents (Miles \& Heberman, 1992; Neuman, 2016; Yusuf, 2014). Furthermore, in qualitative data collection, 17 informants were obtained, consisting of 2 community leaders, 3 RT heads, 3 health cadres, and 9 community members. Determination of informants using a purposive sampling technique, with the criteria (1) Living at the study site for at least 5 years (assumed to be able to interact with residents at the study site), (2) As head of the household (meaning having a minimum family of children and wife/husband), (3) If the target of the head of the family is not at home, then he is replaced by his wife and (4) Willing to be interviewed/asked for information in connection with the GERMAS in accordance with the research topic. Data obtained through in-depth interviews using interview guidelines, observation and Focus Group Discussion (FGD) (Martha \& Kresno, 2016; Soehartono, 2015).

\section{RESULTS AND DISCUSSION}

The seven pillars of GERMAS are (1) Conduct routine health checks. Respondents have never done the reason they feel healthy, why should they go to health services, except for new illness to health services such as Puskesmas or hospitals. This statement is incorrect and is contradicted by a study by Nikander et. al., 2018 and Aribike et. al., 2019, routine health checks into health services provide good opportunities to detect diseases early, such as health services in schools for the care of children at risk of health problems later in life and are considered important, as preventive health services, but they are poor knowledge of preventive health services and difficult to use them.

(2) Performing physical activities, respondents assume that doing daily work such as cleaning boats or fishing boats, repairing fishing nets and catching and selling fish for men. Whereas for women taking care of children, cooking and doing housework are physical activities. The findings of this study when referring to health promotion Deroktorat classified as carrying out daily physical activity (RI Ministry of Health, 2019). Further explained that physical activity can prevent diabetes mellitus, hypertension, coronary heart disease, kidney failure, and stroke. It is recommended to apply the principles of Right, Staged, Structured Teratus (BBTT) that is Good (according to ability), Right (gradual, Turukur (intensity and time) and Organized (3-5 times a week).

(3) Eat vegetables, clean the environment and use the latrine most of the Bengkulu City coastal communities do. The three pillars have been done quite well, although there are still residents who do not pay attention to environmental cleanliness, because they dump garbage in the open. Family latrines are still hitching a neighbor's place. In addition, consuming vegetables has not become a habit to be served every day. Envi- 
ronmental cleanliness is very important, because dirty environment results in the spread of various diseases. The findings in Brazil, clean environment can eliminate diseases, such as schistosomiasis, tuberculosis, leprosy, Chagas disease, leishmaniasis, filariasis, geohelminthiases and trachoma. (Facchini, et.al, 2018), but often overlooked. Study conducted by Guerra at.al, (2018), environmental cleanliness can control malaria. Same with the study conducted by Herlina and Permata, dirty environment, scattered garbage as a vector of mosquitoes which cause many mosquitoes and will cause malaria (Herlina \& Permata, 2019).

Using family toilets, considering the characteristics of coastal waters formed by a combination of seawater, underground rivers, and rainwater, if the environment is not maintained cleanliness will be susceptible to bacteria that cause diarrhea, various Extraordinary Events (KLB) that have occurred due to basic sanitation that does not support, (Ortis et. Al., 2015; Ida, et. Al., 2018). Studies in Tanzania show a strong relationship between access to water and poor sanitation at home, increasing the likelihood of maternal and newborn deaths, sanitation is a basic asset of health in the home (Benova, et. al, 2014).

(4) Eat fruit and consume alcohol, a step was taken by the coastal community. Eating fruit is only consumed during the fruit season because the price is cheaper. The price of fruits is expensive, most family producers are not enough to buy fruit, only able to buy basic necessities, such as buying rice. Referring to the results of the study, fruits containing vitamin $\mathrm{A}$ and folate can prevent the obesity of maintaining nutrition in childhood (Nina et. Al, 2013: Harnack et. Al, 2012). Almost the same as the Sharkey and Dean study (2010), namely the nutritional health of the elderly faces greater challenges because of limited resources, purchasing power, difficulties with transportation, and distance of food resources.

Consuming alcohol is hard to find, even if it is still done clandestinely with a reason to relieve stress and not get drunk. The risk of alcohol consumption is associated with sexual experience, patients with alcohol consumption who are at greater risk of suffering from sexually transmitted diseases (Sullivan, at.al, 2017). The community catches alcohol 'haram' and is prohibited if caught consuming alcohol reported to the authorities or expelled domiciled at the study site.

(5) Not smoking, it is very difficult to find at the study site, because in general, all men are smokers. This condition is difficult to stop because of addiction and has become a habit of citizens. The results of Herlina's research (2018) in the Lebong Regency of Bengkulu Province were found to show smoking male masculinity, considered to be sociable, not stingy, modeled after fathers and social influences. Although various studies have reported the dangers of smoking, even death, but the number of smokers is increasing according to Herlina (2017) especially in the area of Bengkulu Province has a habit when the celebration always provides cigarettes for guests, even when delivery or marriage contract in a place of betel (Rejang language) 'bokoa iben') cigarettes are always 
provided, meaning that they have been entrenched/the habit of invited guests is provided with cigarettes, so it is very difficult to prevent people from stopping smoking. Data revealed (WHO, 2018) smokers around the world have risen to nearly one billion people. In Thailand the results of the study showed that there was a significant reduction in smoking bans, namely reducing the economic burden and health care costs caused by tobacco (Patanavanich, et al, 2018).

Based on the research results, there are 6 variables with p-value $>0.05$, namely father's education, mother's education, highest education in the family, ethnicity, rheumatism / joint pain, and vision, these variables are excluded from the model one by one starting from the variables has the largest $p$-value that is father's education ( $p$-value $=$ 0.552 ), then vision variables ( $p$-value $=0.377$ ), mother's education ( $p$-value 0.376 ), ethnicity ( $p$-value 0.267 ), rheumatism/joint pain ( $p$-value 0.223 ) followed by the expenditure of the highest education variable in the family ( $p$-value $=0.220$ ).

It is known that there is a change in OR> $10 \%$ during the variable expenditure process with a p-value $>0.05$ from the model. This means that the variables of father's education, mother's education, highest education in the family, ethnicity, rheumatism/joint pain, and vision are considered as variables so the final multivariate model conforms to the initial multivariate model.

\section{CONCLUSION}

Based on the results of the study note that there is a change in OR> $10 \%$ during the process of spending a variable with a p-value $>0.05$ from the model, this means the variables of father's education, mother's education, the highest education in the family, ethnicity, rheumatism/joint pain, and vision considered as a confounding variable so that the final multivariate model is in accordance with the initial multivariate model. The most difficult behavior to change is the behavior to stop smoking because it has become a habit, it is not usual to regularly check the health and eating fruit has not been a priority, and daily work is assumed to be physical activity.

\section{REFERENCES}

1. Abubakar, A., Van de Vijver, F. J., Fischer, R., Hassan, A. S., Gona, J. K., Dzombo, J. T., ... \& Newton, C. R. (2016). 'Everyone has a secret they keep close to their hearts': challenges faced by adolescents living with HIV infection at the Kenyan coast. BMC public health, 16(1), 197.

2. Anwar, A., \& Sultan, M. (2016). Derajat Kesehatan Masyarakat Kepulauan di Kecamatan Kepulauan Derawan Kabupaten Berau. HIGIENE: Jurnal Kesehatan Lingkungan, 2(1), 27-32.

3. Aribike, O., Okafor, I., Roberts, A., \& Odugbemi, T. (2019). Are Nigerian women pro-active about noncommunicable disease prevention? A quantitative survey. Annals of global health, 85(1), 1-11. 
4. BP3D Provinsi Bengkulu. (2017). Aksi Daerah Pengembangan Ekonomi Kemaritiman Provinsi Bengkulu Tahun 2017-2020. Badan Perencanaan, Penelitian ban Pengembangan Daerah Provinsi Bengkulu.

5. Benova, L., Cumming, O., Gordon, B. A., Magoma, M., \& Campbell, O. M. (2014). Where there is no toilet: water and sanitation environments of domestic and facility births in Tanzania. PloS one, 9(9).

6. DepKes RI. (2017). Tujuh Pilar Gerakan Masyarakat Hidup Sehat (GERMAS). Direktorat Promosi Kesehatan dan Pemberdayaan Kesehatan, Jakarta.

7. DepKes RI. (2019). Mengenal Jenis Aktivitas Fisik. Direktorat Promosi Kesehatan dan Pemberdayaan Kesehatan, Jakarta.

8. Facchini, L. A., Nunes, B. P., Felisberto, E., da Silva, J. A. M., da Silva Junior, J. B., \& Tomasi, E. (2018). Assessment of a Brazilian public policy intervention to address schistosomiasis in Pernambuco state: the SANAR program, 2011-2014. BMC public health, 18(1), 1200.

9. Guerra, M., de Sousa, B., Ndong-Mabale, N., Berzosa, P., \& Arez, A. P. (2018). Malaria determining risk factors at the household level in two rural villages of mainland Equatorial Guinea. Malaria journal, 17(1), 203.

10. Harnack, L. J., Oakes, J. M., French, S. A., Rydell, S. A., Farah, F. M., \& Taylor, G. L. (2012). Results from an experimental trial at a Head Start center to evaluate two meal service approaches to increase fruit and vegetable intake of preschool aged children. International Journal of Behavioral Nutrition and Physical Activity, 9(1), 51.

11. Herlina, M. (2017). Sosiologi Kesehatan (Paradigma Konsturksi Sosial PHBS dalam Perspektif Peter L. Berger E Thomas Luckmann. Surabaya: Muara Karya.

12. Herlina, M. (2018). Smoking: in Local Wisdom and Social Environment Perspective. Annals of Tropical Madecine and Public Health, 9.

13. Herlina, M., \& Permata, S. P. (2019). Pemberdayaan Kesehatan Masyarakat Pesisir: Optimalisasi Kegiatan Posyandu. Jurnal DIANMAS, 8(1).

14. Herlina, M., \& Permata, S. P. (2019). Dinamika Masyarakat Kontemporer (Perilaku Masyarakat dan Nilai Sosial Budaya Dalam Mengurangi Penyebaran Penyakit Malaria). Yogyakarta: Idea Press.

15. Hidana, R., Shaputra, R., \& Maryati, H. (2018). Faktor-Faktor yang Berhubungan dengan Pemanfaatan Pelayanan Kesehatan oleh Pasien Luar Wilayah di Puskesmas Tanah Sareal Kota Bogor Tahun 2018. PROMOTOR, 1(2), 105-115.

16. Muslikhah, I., Lestari, H., \& Afa, J. R. (2018). Identifikasi Masalah Kesehatan Berbasis Lingkungan di Wilayah Pesisir Desa Wawatu Kecamatan Moramo Utara Kabupaten Konawe Selatan Tahun 2017. Jurnal Ilmiah Mahasiswa Kesehatan Masyarakat, 3(1).

17. Latif, I. (2016). Analisis Deskriptif Masalah Kesehatan Masyarakat Pesisir Desa Karangsong-Indramayu. Jurnal Kesehatan Indra Husada, 4(2), 29-36.

18. Lasabuda, R. (2013). Pembangunan wilayah pesisir dan lautan dalam perspektif Negara Kepulauan Republik Indonesia. Jurnal Ilmiah Platax, 1(2), 92-101. 
19. Martha, E., \& Kresno, S. (2016). Metodologi Penelitian Kualitatif untuk Bidang Kesehatan. Jakarta: PT. Rajagrafindo Persada.

20. Milles, M. B., \& Huberman, A. M. (1992). Analisis Data Kualitatif: Buku Sumber Tentang Metode-Metode Baru. Jakarta: UIP.

21. Muraya, K. W., Jones, C., Berkley, J. A., \& Molyneux, S. (2016). Perceptions of childhood undernutrition among rural households on the Kenyan coast-a qualitative study. BMC public health, 16(1), 693.

22. Muri, Y. (2014). Metode Penelitian Kuantitatif, Kualitatif E Penelitian Gabungan. Jakarta: Prenadamedia Group.

23. Nafsiah, M. (2015). Masyarakat-pesisir-perlu-perhatian-khusus-untuk-masalahkesehatan, https://www.voaindonesia.com. Accessed 28 July 2019.

24. Napirah, M. R., Rahman, A., \& Tony, A. (2016). Faktor-Faktor Yang Berhubungan Dengan Pemanfaatan Pelayanan Kesehatan Di Wilayah Kerja Puskesmas Tambarana Kecamatan Poso Pesisir Utara Kabupaten Poso. Jurnal Pengembangan Kota, 4(1), 29-39.

25. Neuman, L. W. (2016). Metode Penelitian Sosial: Pendekatan kualitatif dan Kuantitatif. Jakarta: Indeks.

26. Nikander, K., Kosola, S., Kaila, M., \& Hermanson, E. (2018). Who benefit from school doctors' health checks: a prospective study of a screening method. BMC health services research, 18(1), 501.

27. Nina, N., Kalesaran, A. F., \& Langi, F. L. F. G. (2018). Hubungan Antara Aktivitas Fisik dengan Kualitas Tidur pada Masyarakat Pesisir Kota Manado. KESMAS, 7(4).

28. Noni, Y. (2017). Badan Perencanaan, Penelitian Dan Pengembangan Daerah Provinsi Bengkulu Tahun 2017, Rencana Aksi Daerah Pengembangan Ekonomi Kemaritiman Provinsi Bengkulu.

29. Ortiz-Carrillo, I., Estrella-Gómez, N. E., Zamudio-Maya, M., \& Rojas-Herrera, R. (2015). Diversity of Vibrio spp in karstic coastal marshes in the Yucatan Peninsula. PloS one, 10(8).

30. Patanavanich, R., Aekplakorn, W., \& Suriyawongpaisal, P. (1952). Trend analysis of smoking-attributable hospitalizations in Thailand, 2007-2014. Tob. Induc. Dis, 2018, 16.

31. Pramudyanto, B. (2014). Pengendalian Pencemaran dan Kerusakan di Wilayah Pesisir. Jurnal Lingkar Widyaiswara, 1 (4), 37-38.

32. Rachman, B. N., Mustika, I. G., \& Kusumawati, I. A. W. (2017). Faktor yang berhubungan dengan perilaku konsumsi buah dan sayur siswa SMP di Denpasar. Jurnal Gizi Indonesia (The Indonesian Journal of Nutrition), 6(1), 9-16.

33. Rohidin, M. (2018). Plt. Gubernur Minta Wilayah Pesisir Dioptimalkan, https://bengkuluprov.go.id/plt-gubernur-minta-wilayah-pesisir-dioptimalkan/. Accessed November 23, 2019. 
34. Routray, P., Torondel, B., Clasen, T., \& Schmidt, W. P. (2017). Women's role in sanitation decision making in rural coastal Odisha, India. PloS one, 12(5).

35. Sharkey, J. R., Johnson, C. M., \& Dean, W. R. (2010). Food access and perceptions of the community and household food environment as correlates of fruit and vegetable intake among rural seniors. BMC geriatrics, 10(1), 32.

36. Soehartono, I. (2015). Metode Penelitian Sosial. Bandung: Remaja Rosdakarya.

37. Sullivan, C., Martin, N., White, C., \& Newbury-Birch, D. (2017). Assessing the delivery of alcohol screening and brief intervention in sexual health clinics in the north east of England. BMC public health, 17(1), 884.

38. Suyanto, G. (2016). Pemprov Tetapkan Kawasan Kampung Nelayan Sejahtera, https://www.nusantaraterkini.com/pemprov-tetapkan-kawasan-kampung-nelayansejahtera, accessed 12 January 2019. 